"Japan/religion") might merely serve to provide an anachronistic set of hermeneutic frames without necessarily achieving the anthology's aim of "illustrat[ing] the diversity of thought [and] the evolution of the various [Kokugaku] schools" (7).

In its presentation and translation of important Kokugaku texts that have hitherto not been adequately examined in English language scholarship, this anthology makes an important contribution to the study of this historically significant movement. However, its anachronistic frames as well as its assumption of implicit nativism should best be viewed with some skepticism. Ultimately, this collection does not seem intended as an engagement with the question, "What is Kokugaku?" in spite of the anthology's aim of putting it on display. This task is rather left up to the reader, along with ample tools to approach this formidable task.

\title{
“Joryū" hōdan: Shōwa o ikita josei sakka-tachi
}

By Irmela Hijiya-Kirschnereit. Tokyo: Iwanami shoten, 2018. 405 pp. $¥ 3,190$.

\section{Reviewed by Noriko J. Horiguchi}

"Joryū" hōdan: Shōwa o ikita josei sakka-tachi ("Women's style" free conversations: Women writers who lived through the Shōwa era, <女流> 放談—昭和を生きた女性作家達) combines (1) Irmela Hijiya-irschnereit's 2018 essay “'Joryū bungaku' ga bungaku ni naru hi: Josei sakka ga morashita 'nama' no koe" (The day "women's literature" becomes literature: Women writers' "raw" voices), and (2) a collection of her 1980s interviews of twelve well-known modern Japanese women authors: Sata Ineko (1904-1998), Enchi Fumiko (1905-1986), Kono Taeko (19262015), Ishimure Michiko (1927-2018), Tanabe Seiko (1928-), Saegusa Kazuko (1929-2003), Ōba Minako (1930-2007), Togawa Masako (19312016), Tsushima Yuko (1947-2016), Kanai Mieko (1947-), and Nakayama Chinatsu (1948-). Also included are Hijiya-Kirschnereit's 2018 interview of Setouchi Jakuchō (1922-) and Itō Hiromi’s brief 2018 essay about the interviews. Although Hijiya-Kirschnereit's original

Japanese Language and Literature $\mid$ jll.pitt.edu

Vol. 54 | Number 1 | April 2020 | DOI: https://doi.org/10.5195/j11.2020.145 
intention was to introduce German readers to Japanese women authors, the main audience for this volume seems to be general Japanese-speaking readers because it is written in Japanese and contains no academic jargon or theoretical analysis.

In this volume, Hijiya-Kirschnereit and the authors she interviews stand on "equal" (395) planes and engage in conversations based on a set of questions that spark free-flowing dialogue. During the interviews, Hijiya-Kirschnereit's ideas, based on her academic, personal, and professional experiences in Japan and Germany, come across as strongly as (and sometimes more strongly than) those of the authors she interviews. She not only listens and agrees but sometimes disagrees with their responses and challenges them with her own set of ideas. Published three and half decades after the interviews were originally conducted, this volume also includes 2018 remarks by Hijiya-Kirschnereit and a few of her interviewees, who are now in their seventies, eighties and nineties. These remarks (somewhat nostalgically) reflect upon the changes and continuity between the 1980s and today, in terms of these women writers' personal and professional experiences; literary, academic, social, and publishing institutions; and the readership of Japanese women's literature in Japanese- and German-speaking communities.

Hijiya-Kirschnereit began her investigation via interviews because of a gap in readers' knowledge of women's literature in modern and contemporary Japan. Although classical Japanese works written by aristocratic women in the Heian court had been well known in Europe and the United States since the early twentieth century, modern and contemporary works by Japanese women were treated lightly and superficially until the 1970s. Higuchi Ichiyō and Yosano Akiko were highly thought of, but were seen as exceptions to women's generally marginalized position. Until 1970, all Japanese literary works translated into foreign languages were by male writers, such as Tanizaki Jun'ichirō, Kawabata Yasuanari, Mishima Yukio, Natsume Sōseki, Mori Ōgai, Nagai Kafū, Akutagawa Ryūnosuke, and Abe Kōbō.

When works written by women received attention in the 1970s, they were labeled joryū bungaku (women's literature), mainly by male writers. For example, in 1974, Okuno Tateo wrote an essay entitled "Joryū sakka ron: shōsetsu wa honshitsu-teki ni josei no mono ka" ("Treatise on women writers: Is the novel essentially feminine?). In 1976, Kokubungaku (National literature), a journal that specializes in Japanese literature, published a special issue on jory $\bar{u}$ bungaku for the first time, with the theme "Joryū bungaku no genzai" (The present state of women's

Japanese Language and Literature $\mid$ jll.pitt.edu

Vol. 54 | Number 1 | April 2020 | DOI: https://doi.org/10.5195/j11.2020.145 
literature). In 1977, Iwaya Daishi (1915-2006) published Monogatari jory $\bar{u}$ bundan-shi (Narratives in the history of the women's literary establishment). In 1980, a special issue entitled Kokubungaku: Joryū no zensen: Higuchi Ichiyō kara hachijü nendai no sakka made (Frontline of joryu $\bar{u}$ in national literature: From Higuchi Ichiyo to writers in the 1980s) was published. Despite (or because of) these publications, biased and stereotypical views of literature written by women in Japan persisted. Women's writing was perceived as private and particular, emotional, and narrow.

In the early 1980s, Hijiya-Kirschnereit was a junior scholar of Japanese literature from Germany and was perplexed by the frequent references to joryū bungaku in Japan. She wondered whether this ambiguous term referred to an author's gender/sex, the target readership for literature that is produced by women for women, or the nature or aesthetics of literature that is characterized as feminine. Based on her readings in Japanese and German, she posits that there are "clear differences between the Japanese and Western languages" and that "the language of sexual differences and Japanese aesthetics are connected" (332). Furthermore, she found, "the category of sexual difference is ... a definitive standard" and is a more absolute element than the elements of "age" and "social class and hierarchy that form the Japanese language" (332). Although she is aware of a "risky attempt at recognizing something like the 'uniqueness of Japan' and falling into stereotypical nihonjin-ron," her writing is based on the dualism of Japan versus Germany or Europe, and their linguistic, aesthetic, cultural, and religious differences $(71,88-$ 93). She asserts that "what can be said with considerable certainty is that in Japanese society, the tendency to view and understand the world based on categories of sex is stronger than in other cultural spheres, both historically and in the contemporary era" (333). Hijiya-Kirschnereit concludes that in Japan "codes of human behavior, understanding of one's self, and views of the world are divided by sex and aestheticized" and that "aestheticization exists as part of the power structure, and functions as a means to skillfully hide it, and secretly solidify inequality" (333).

Hijiya-Kirschnereit selected Japanese women writers whose works range from novels, essays, poetry, and plays to proletarian literature, mystery novels, and experimental collages of fact and fiction. Some write "pure" literature that is published by prestigious publishers and journals, while others produce entertaining tales for the masses that are serialized in newspapers. By meeting women writers in person at their homes and

Japanese Language and Literature $\mid$ jll.pitt.edu

Vol. 54 | Number 1 | April 2020 | DOI: https://doi.org/10.5195/j1l.2020.145 
offices, Hijiya-Kirschnereit also encountered a variety of human characteristics, images, and lifestyles.

Although her interviewees disagree with the label jory $\bar{u}$ bungaku, Hijiya-Kirschnereit finds that she "could not elicit from anyone radical opinions or expressions that stand out," even though she invites such ideas by using combative vocabulary and cites concrete examples of obviously unequal and unfair facts and situations (319). Kanai Mieko, for example, is critical of the world of knowledge constructed by men in Western society, and of political philosophy within the development of the social system as a means of control by men in the West, but never thought of or planned to write a work of literature that expresses a political opinion. As Hijiya-Kirschnereit explains, the women writers she interviewed seemed more concerned about pragmatic tactics in balancing work and family obligations, and in interacting with the publishing industry, editors, critics (hyöronka), and readers (academic and non-academic).

In her interviews, Hijiya-Kirschnereit also repeatedly points out the tradition of "I-novels" in Japan, and problematizes the extensive focus by editors, publishers, and readers on an author's lifestyle and on her/his texts as a reflection of it, as well as the disproportionate emphasis on women writers' (versus men writers') personal and private lifestyles. The irony is that Hijiya-Kirschnereit herself also focuses on the individual women authors' personal/private and professional lives and experiences, and their intentions/ideals/ideas. Overall, the authors' ideas expressed and described in this volume may come across as much less provocative, witty, or enriching than their literary texts themselves. This may be especially true for scholars of Japanese literature trained in post-New Criticism of the 1920 s and post-structural readings after the late 1960s, who focus on texts as contexts, and on texts within contexts, rather than on their authors' intentions, characters, and lifestyles.

Nevertheless, Ōba Minako, for example, states that women are superior in giving birth to metaphysical and literary works because of their biological and physical reproductive ability, and that the source of all energy (for activities and achievements) derives from what is feminine. Tsushima Yūko sees writing a novel as a political endeavor that resists or questions the status quo, such as conventional views of motherhood. Kōno Taeko equates participation in literature with participation in women's liberation and forming thoughts. Saegusa Kazuko wishes to write about women's perspectives on war, and women's positions in the defeated nation. And Ishimure Michiko seeks ways to participate with language in the contemporary period of suffering and to renew the people.

Japanese Language and Literature $\mid$ jll.pitt.edu

Vol. 54 | Number 1 | April 2020 | DOI: https://doi.org/10.5195/j11.2020.145 
After Hijiya-Kirschnereit's 1980s interviews revealed that these twelve women writers all disputed the categorization of their writing as jory $\bar{u}$ literature, the term jory $\bar{u}$ came to be problematized in Japan, as reflected in seminal publications and changes in the literary establishment (bundan). In 1986, Hijiya-Kirschnereit published an article entitled "Joryū bungaku ga bungaku ni naru hi" (The day joryū literature becomes literature) in Asahi shinbun. In 1987, Kōno Taeko and Ōba Minako became the first women members of the Akutagawa Award selection committee. In the 1990s, numerous publications problematized the description jory $\bar{u}$ bungaku. For example, Kanai Mieko and Saegusa Kazuko wrote books and essays that analyze men's bias in literature. In 1992, Danryū bungaku-ron (Treatise on men's style literature) was published by the sociologist Ueno Chizuko, psychologist Ogura Chikako, and novelist Tomioka Taeko. As a result, women writers brought skillful literary expressions of sexual/gender discrimination into general discussion in Japan. Eight years later, in 2000, the "Joryu literature award" was abolished. To Hijiya-Kirschnereit, whose aim is to overcome and erase the term joryu, this seems to mark the time when women's literature "begins to be accepted as universal" and when "writers [I interviewed] will be satisfied" (356).

The year 1982 marked an important change in the study of Japanese women's literature, not only in Japan but also in Germany. Unbeknownst to Hijiya-Kirschnereit when she was conducting her interviews that same year, works were appearing in English that focused on women's literature from Japan: Yukiko Tanaka and Elizabeth Hanson, eds., This Kind of Woman: Ten Stories by Japanese Women Writers, 1960-1976 (Stanford University Press); Noriko Mizuta Lippit and Kyoko Iriye Selden, trans. and eds., Stories by Contemporary Japanese Women Writers (M. E. Sharpe); and Phyllis Birnbaum, trans., Rabbits, Crabs, Etc.: Stories by Japanese Women (University of Hawai'i Press). Thus, Hijiya-Kirschnereit asserts, 1982 marks contemporary Japanese women's literature's entry onto the stage in European and American society.

Her interviews in the early 1980s in Japan also coincided with Japanese women writers beginning to receive attention in Germany, with the publication of anthologies and translations of women's literature into German. Between the early 1980s and 2018, Hijiya-Kirschnereit became an effective translator of Japanese women's literature into German and the major force behind the growing readership of Japanese women's literature in Germany. This was an outcome of the late 1970s movement in European languages to focus on and explore literature written by women. In West

Japanese Language and Literature $\mid$ jll.pitt.edu

Vol. 54 | Number 1 | April 2020 | DOI: https://doi.org/10.5195/j1l.2020.145 
Germany, Rewohlt Verlag established a paperback series called "New Women" and, from 1977 to 1995, introduced many women writers' texts, not only from German-language communities but also other nations. In the 1980s, the largest publisher in Germany, Suhrkamp, asked HijiyaKirschnereit to become the editor of a 32-volume series on Japanese literature. This meant rapidly increasing interest in Japanese literature in Germany in the 1980s. In 1990, at the world-famous Frankfurt Book Fair, Japan was selected as the country of theme.

Along with Hijiya-Kirschnereit's translation projects came changes in the book market, general readership, and studies of Japanese women's literature in the German-language community. As discussed above, Hijiya-Kirschnereit's focus is on publications and studies on women's literature in German- and Japanese-language communities. Her 2018 volume reviewed here complements Joan E. Ericson's careful analysis in her Be a Woman: Hayashi Fumiko and Modern Japanese Women's Literature (University of Hawai'i Press, 1997), which pointed out that the literary category joryū bungaku associated sentimentality, lyricism, and impressionism with works of literature written by women, erasing individual differences in women and in each work of literature by the same author. Read in conjunction with Ericson's analysis, Hijiya-Kirschnereit's volume helps us understand the personal and literary history of individual authors, the development of the publishing industry, general and academic readership, and studies of modern Japanese women's literature in the Japanese-, German-, and English-language communities.

\section{Japanese Kanji Power: A Workbook for Mastering Japanese Characters}

By John Millen. Tokyo: Tuttle Publishing, 2010. xiii, 304pp. $\$ 26.95$.

\section{Reviewed by Karen Curtin}

Japanese Kanji Power: A Workbook for Mastering Japanese Characters (hereafter, $J K P$ ) boasts 464 kanji in one book, including all kanji on the Advanced Placement (AP) exam in Japanese language, in levels 4 and 5 of the Japanese Language Proficiency Test (JLPT), and taught in Japanese school Grades 1 and 2. It should be noted that since the workbook was

Japanese Language and Literature $\mid$ jll.pitt.edu

Vol. 54 | Number 1 | April 2020 | DOI: https://doi.org/10.5195/j11.2020.147 